\title{
Inclusion of Sex Education in School Curriculum of Bangladesh: Parents' Attitude
}

\author{
Mohammad Kowsar Bhuiyan \\ Researcher,EIA-DU-OU (UK) Research Collaboration Programme \\ Institute of Education and Research, University of Dhaka, Bangladesh \\ kowsarbhn@hotmail.com, +8801557614688
}

\begin{abstract}
The study examined the attitude of Bangladeshi parents' regarding inclusion of sex education in school curriculum of Bangladesh. Using 21 topics of comprehensive sex education, parents were asked to explore which topics they believed should be taught in schools. The study also assessed the relationship between the parents' demographic characteristics (residence, sexual orientation, religious belief, occupation, and educational background) and their attitude towards sex education. The study found that $48.3 \%$ parents support sex education whilst $25 \%$ parents did not support sex education and rests were found neutral position among 120 sampling size. Most of the parents supported the topics of sex education which were mostly value and culture oriented instead of the knowledge of sexual intercourse, abortion, taking protection for premarital sexual activity etc. Moreover, form Chi-square test the study found that there had significance difference between the attitude of parents towards inclusion of sex education and their residence, occupation or educational background.
\end{abstract}

Keywords: Sex Education, School Curriculum, Parents'Attitude, Bangladesh.

\section{Background Of The Study}

Sex is a biological affair and essential for existence of human being (Barkat \& Majid, 2003). Sometimes it may cause many problems and at present the world has been facing those problems immensely. HIV/AIDS is one of them and has been appeared as a pandemic, as of 2010 there were about34 million people around the world living with HIV/AIDS, with 2.7 million newly infected with HIV and 1.8 million annual deaths due to AIDS(WHO, UNAIDS, UNICEF, 2011). To extent, 5 million young people around the world are living with HIV (UNICEF, 2011). Not only HIV/AIDS, but also unsafe and unprotected sex cause many other problems, which are reckoned as "sexually transmitted diseases or infections (STD/I)" (Sexually Transmitted Diseases and STD Symptoms, 2011). Furthermore, ignorance of concerning sexuality, contraception and responsible sexual behavior can expedite teenage pregnancies, abortion and premature death (Myeza, 2008). Therefore, to solve this demolition, human being needs to acquire proper knowledge about safe, healthy and protected sexual behavior and for this reason educating sex education for the teenagers or school going children is very important. That is why sex education is very important one at present world.

The diversity of the AIDS epidemic is greater in Asia than in Africa, about 4.9 million people are living with HIV in different parts of south, east and south-east Asia (UNAIDS, 2010). However, there are three main HIV transmission routes in Asia, two routes are straightaway mired with human sexual behavior- unprotected sex, sex between men and injecting drug use (UNAIDS, 2009; UNAIDS, 2008). A recent report estimated that 150,000 children in south and south-east Asia were living with HIV and in east Asia it was about 8,000 children, most of them became infected through mother-to-child transmission (UNAIDS, 2010). In Bangladesh, though the problem of AIDS is still fairly small scale (UNAIDS, 2010), but it is presume that in future Bangladesh may gradually face an epidemic unless a greater initiativeis developed (UNAIDS, 2008). According to the report of different NGOs have been working in the field, the present number of HIV patients in Bangladesh is not an exact figure, the number is moderate but it may dramatically raise.

As a signing country in the Millennium Development Goals (MDGs), Children's Rights Convention (CRC), and the Convention to Eliminate Discrimination against Women (CEDAW) Bangladesh is committed to establish adolescents' right to sex education. Besides, MDGs fifth and sixth goals are set to reduce maternal mortality rate, to achieve universal access to reproductive health and to reverse the spread of HIV/AIDS by 2015 (UNICEF, 2010). The Children's Rights Committee suggested confirming adolescents' right to access sufficient information essential for their health and development to participate meaningfully in the society (The Reproductive Rights of Adolescents: A Tool for Health and Empowerment, 2011). The CEDAW also recommends on the importance of comprehensive sex education, especially with regard to preventing the spread of HIV/AIDS (CEDAW, 1990).

To achieve the goals mentioned in CEDAW, CRC, and MDGs Bangladesh has develop some policies for adolescents reproductive health, combating HIV/AIDS epidemic, STDs, STIs, unwanted pregnancies etc. 
According to the national policies on HIV/AIDS and STD related issues and National Strategic Plan for HIV/AIDS 2004-2010 all formal and non-formal educational institutions to have HIV/AIDS/STD education in curriculum as a personal and developmental issues along with capacity building for teaching and research, and firming conversation forum and research on these issues (National AIDS Committee, 1996; Government of the People's Republic of Bangladesh). Likewise, Bangladesh population policy and adolescents reproductive health strategy suggest effective propagation of adolescent reproductive health knowledge and information through school syllabuses in secondary and higher secondary school along with review and modification of existing syllabuses and its proper execution in classroom teaching-learning process ( Government of the People's Republic of Bangladesh, 2004; Barkat \& Majid, 2003). It also suggests, universities taking the necessary steps to modify demographic/population and reproductive health courses.

Despite having policies the reality is totally different and it is rare to find effective sex education program for the adolescents. Though some NGOs are working to promote sex education through non-formal approach but it covers very limited and selective area for some targeted groups. Therefore, most of the adolescents are remaining out of the program. Nevertheless, in formal education, secondary school curriculum offers a little knowledge about HIV/AIDS and human reproduction process through some courses according biology that does not have the desired elements of sex education as Bangladesh authorities said in their policies and laws (PLAN, 2010).

To extent, sex education refers to educational goals that are broader than simply biology (Comprehensive Sexuality Education, 2011). At minimum, it should include information about anatomy and physiology, puberty, pregnancy and STIs e.g. HIV/AIDS along with the knowledge to defending sexual abuse and behavior with opposite sex as sex education topics (Kabir, Karim, \& Akhter, 2005). One of the important goals of sex education is to assist adolescents to develop independence using skills such as communication, decision-making, and negotiation (Kirby \& Laris, Effective Curriculum-Based Sex and STD/HIV Education Programs for Adolescents, 2009). Sex education covers six concepts e.g. i) relationships; ii) values, attitude and skills; iii) culture, society and human rights; iv) human development; v) sexual behavior; and vi) sexual and reproductive health (UNESCO, 2009).

A prescribed curriculum is a commendable delivery vehicle for sex education, which also include involving with teacher education, regulation and support as well as assessment process concerned with evaluating results. In addition, the curriculum needs to be appropriate in terms of learners' age and culture and it must address the representativeness of their lives, including their sexual belief and behavior (PLAN, 2010). As these are the very relevant for Bangladesh, so these should consider in terms of inclusion of sex education in school curriculum.

Parents are the most vital and prime source of guidance for young children bearing in mind sexual behavior and values (Frappier, et al., 2008). Nevertheless, for Bangladeshi parents, sex is a dirty word and they feel uncomfortable in conversing sex and sexual affair with their children, because they are often brought up in a state of ignorance about sex issues along with their cultural up bearing and religious training. However, the parents are not aware that on an average a child is exposed to 9000 sexual scene per year (Athar, 1995). These parents should know that sex is not always dirty (Kabir, Karim, \& Akhter, 2005).

Parents have the right of choosing what topics should be educated their children and what to be incorporated in school curriculum (Adler, 1993). Before this, the universal declaration of human right 1948 have specified in its article 26(3) that 'parents have a prior right to choose the kind of education that shall be given to their children' (United Nations, 1948). So, on the issues of sex education, parental involvement is mandatory to decide what courses their children should be taught and at what level it should be included. If parents are worried about the suitability of curriculum content or unwilling to occupy in what their children learn through sexuality education packages, the probabilities of individual growth for children or young people are likely to be incomplete (UNESCO, 2009).

Therefore, it has become clear that providing sexual knowledge to adolescents' parents are playing major role as their role in inclusion of sex education in school curriculum and it is essential to examine parents' attitude and the factors what can influence their attitude towards inclusion of sex education.

\section{Objectives Of The Study}

The study focused on following research objectives:

1. To explore parents' agreement on incorporating different issues of sex education in school curriculum.

2. To find out the differences between the attitude of rural and urban parents' towards sex education

3. To examine the influence of parents' sexual orientation, religious belief, level of education and their attitude towards incorporating sex education.

The hypothesis of this study were as following-

1. $\mathrm{H}_{0}$ : The attitude of parents' towards inclusion of sex education in school curriculum is neutral.

2. $\mathrm{H}_{0}$ : There has no weighty difference in attitude of rural and urban parents towards inclusion of Sex 
Education.

3. $\mathrm{H}_{0}$ : There is no significant difference between parents approach regarding inclusion of Sex Education contents irrespective of religious belief, gender, occupation, and level of education.

\section{Methodology}

The design used in this study is operated in descriptive approach where quantitative data has been gathered from the survey. As, the descriptive design of a study aims to provide an accurate quantitative description of a phenomenon rather than discovering the cause for it and here is no manipulation of subjects, so researcher has to measure the things as they are (McMillan \& Schumacher, 1993).

\subsection{Research Instrument}

A modified and contextualized version of questionnaire designed by Makol-Abdul, Nurullah, Imam and Rahman (2009) was used in this study for data collection, which was consisting of two sections. The first section of the questionnaire was collecting parents' demographic information's and few warm up questions about sex education, whereas the second part of the questionnaire was consisted of Likert scale type items, where parents were asked to respond to a series of statements using a Likert scale from 1 to 5, as follows:

1 (Strongly Disagree) - 2 (Disagree) - 3 (Neutral) - 4 (Agree) - 5 (Strongly Agree)

In associated with the objectives of the study, the questionnaire items addressed three aspects: parent' demographics background, their knowledge on sex education and their ratings on different sex education topics which illustrated their attitude towards inclusion of sex education.

\subsection{Participants And Data Analysis Procedure}

The main sources of data used form field survey which was taken place in Dhaka city as urban representative and Rajbari as rural representative in Bangladesh.

One hundred and twenty parents were involved in the survey study. Respondents were equally distributed for both sex between Dhaka and Rajbari area. Five schools were selected through simple random sampling fromthe respectedareas.

In the study data and evidence were analyzed using the statistical package for the social science (SPSS), version 18.0 for windows and Microsoft Excel 2010.

\section{Findings}

Parents'rating on 21 statements on Sex Education was as following:

Table 1 : Parents' rating on 21 topics of Sex Education $(n=120)$

\begin{tabular}{|c|c|c|c|c|c|c|c|}
\hline \multicolumn{2}{|c|}{ Topics } & \multirow{2}{*}{$\begin{array}{l}\text { Strongly } \\
\text { Disagree } \\
1 \\
\end{array}$} & \multirow{2}{*}{$\begin{array}{l}\text { Disagree } \\
2 \\
\end{array}$} & \multirow{2}{*}{ Neutral } & \multirow{2}{*}{$\begin{array}{l}\text { Agree } \\
4\end{array}$} & \multirow{2}{*}{$\begin{array}{l}\text { Strongly } \\
\text { Agree } \\
5 \\
\end{array}$} & \multirow{2}{*}{$\begin{array}{l}\text { Mean } \\
\text { Score }\end{array}$} \\
\hline & & & & & & & \\
\hline 1 & Family formation and family values & - & - & - & $60.0 \%$ & $40.0 \%$ & 4.40 \\
\hline 2 & Tolerance and respect towards the opposite sex & - & - & - & $71.7 \%$ & $28.3 \%$ & 4.28 \\
\hline 3 & Eliminate gender-based violence & $1.7 \%$ & $1.7 \%$ & $28.3 \%$ & $46.7 \%$ & $21.7 \%$ & 3.85 \\
\hline 4 & $\begin{array}{l}\text { Positive contact with family members about sexuality } \\
\text { in adolescent period }\end{array}$ & $26.7 \%$ & $13.3 \%$ & $11.7 \%$ & $36.7 \%$ & $11.7 \%$ & 2.93 \\
\hline 5 & Family, social and national values about sexuality & - & $6.7 \%$ & $31.7 \%$ & $48.3 \%$ & $13.3 \%$ & 3.68 \\
\hline 6 & $\begin{array}{l}\text { Unsafe, risk and harmful sources to get sexual } \\
\text { knowledge }\end{array}$ & $6.7 \%$ & $16.7 \%$ & $30 \%$ & $31.7 \%$ & $15 \%$ & 3.32 \\
\hline 7 & $\begin{array}{l}\text { Reproductive organs and their functions of male and } \\
\text { female }\end{array}$ & $20.0 \%$ & $21.7 \%$ & $21.7 \%$ & $35.0 \%$ & $1.7 \%$ & 2.77 \\
\hline 8 & Knowledge about adolescent physical changes & $15.0 \%$ & $15.0 \%$ & $16.7 \%$ & $45.0 \%$ & $8.3 \%$ & 3.17 \\
\hline 9 & Knowledge about changes of adolescent social attitude & $3.3 \%$ & $5.0 \%$ & $28.3 \%$ & $48.3 \%$ & $15.0 \%$ & 3.67 \\
\hline 10 & $\begin{array}{l}\text { Knowledge about sexually transmitted diseases and } \\
\text { infections and their prevention }\end{array}$ & $5.0 \%$ & $10.0 \%$ & $18.3 \%$ & $53.3 \%$ & $13.3 \%$ & 3.60 \\
\hline 11 & $\begin{array}{l}\begin{array}{l}\text { Knowledge about HIV/AIDS diseases and its } \\
\text { prevention }\end{array} \\
\end{array}$ & - & $1.7 \%$ & $21.7 \%$ & $51.7 \%$ & $25.0 \%$ & 4.00 \\
\hline 12 & Birth control, adolescent pregnancy and its prevention & $16.7 \%$ & $20.0 \%$ & $16.7 \%$ & $38.3 \%$ & $8.3 \%$ & 3.02 \\
\hline 13 & Teenage parenthood and its risk & $15.0 \%$ & $28.3 \%$ & $23.3 \%$ & $23.3 \%$ & $10.0 \%$ & 2.85 \\
\hline 14 & Reproduction and pregnancy & $33.3 \%$ & $20.0 \%$ & $13.3 \%$ & $26.7 \%$ & $6.7 \%$ & 2.53 \\
\hline 15 & Alternative ways of abortion & $30.0 \%$ & $16.7 \%$ & $30.0 \%$ & $20.0 \%$ & $3.3 \%$ & 2.50 \\
\hline 16 & Natural way of family planning & $18.3 \%$ & $26.7 \%$ & $20.0 \%$ & $30.0 \%$ & $5.0 \%$ & 2.77 \\
\hline 17 & Prevention of child sexual abuse and harassment & $3.3 \%$ & $1.7 \%$ & $30.0 \%$ & $45.0 \%$ & $20.0 \%$ & 3.77 \\
\hline 18 & $\begin{array}{l}\text { Knowledge regarding the prevention of rape and eve- } \\
\text { teasing }\end{array}$ & $3.3 \%$ & $10 \%$ & $33.3 \%$ & $40 \%$ & $13.3 \%$ & 3.50 \\
\hline 19 & Decisions about sexuality & $56.7 \%$ & $13.3 \%$ & $15 \%$ & $13.3 \%$ & $1.7 \%$ & 1.90 \\
\hline 20 & Healthy and safe physical relation & $48.3 \%$ & $20.0 \%$ & $11.7 \%$ & $16.7 \%$ & $3.3 \%$ & 2.07 \\
\hline 21 & $\begin{array}{l}\text { Practicability of knowledge to establish a sexual } \\
\text { relationship ante-nuptial }\end{array}$ & $60.0 \%$ & $21.7 \%$ & $6.7 \%$ & $8.3 \%$ & $3.3 \%$ & 1.73 \\
\hline
\end{tabular}


Findings summarized in table 1 showed parental disposition for inclusion of numerous sex education topics in school curriculum. To make the analysis easier Five Point Likert scale was being converted into Three Point Likert scale, where 'Strongly Disagree and Disagree' were converted into one category named 'Negative', 'Agree and Strongly Agree' were considered as 'Positive' category and Neutral remained same. Among 21 issues on sex education, "family formation and family values" and "tolerance and respect towards the opposite sex" found 100\% approval by the respondents. On the other hand, "decision about sexuality", "healthy and safe physical relation" and "practicability of knowledge to establish a sexual relationship ante-nuptial" had seen opposite scenario where most of the parents were not supportive with these topics, the negative percentage was $70 \%, 68.3 \%$ and $81.7 \%$ respectively. Conversely, positive response was found for "eliminate gender-based violence", where $68.4 \%$ parents were approving this topic. Moreover, similar results were found for "knowledge about HIV/AIDS diseases and its prevention", "knowledge about sexually transmitted diseases and their prevention", "knowledge about changes of adolescent social attitude", "family, social and national values about sexuality", "knowledge about adolescent physical changes", "positive contact with family members about sexuality in adolescent period" and "birth control, adolescent pregnancy and its prevention" for providing sex education, where most of parents were giving their positive response on these topics. The positive percentages for these topics were 76.7, 66.6, 63.3, 61.6, 53.3, 48.4 and 46.6 respectively. However, for the statements of "teenage parenthood and its risk", "reproduction and pregnancy", "alternative ways of abortion" and "natural way of family planning" parents had given mixed opinion. The negative percentages of these topics were 43.3, 53.3, 46.7 and 45 respectively whereas the positive percentages were 33.3, 33.4, 23.3 and 35 successively and rests were neutral. On the other hand, for the statement of "Unsafe, risky and harmful sources to get sexual knowledge" the study found that about $46.7 \%$ respondents were positive while $23.4 \%$ respondents were negative and rest were neutral. Nonetheless, most of the respondents' opinion was negative on "reproductive organs and their functions of male and female", the negative percentage was about 41.7 whereas positive percentage was 36.7 and other is neutral. On the contrary, the results found positive for "prevention of child sexual abuse and harassment" and "knowledge regarding the prevention of rape and eve teasing". Majority of respondents had positive response on these topics; the percentages were about 65 and 53.3 correspondingly.

\subsection{Hypothesis Testing}

As mentioned earlier that for the facilitation of data interpretation three scale attitude named Negative, Neutral and Positive are used in data analysis, where a data range is used for determining these three scale attitude. Following table has illustrated the whole description-

Table 2 : Defining data range

\begin{tabular}{lllll}
\hline 5 Scale & Point & Data Range & New Data Range & 3 Scale Attitude \\
\hline Strongly Disagree & 1 & $0.51-1.50$ & $0.51-2.50$ & \multirow{2}{*}{ Negative } \\
Disagree & 2 & $1.51-2.50$ & & Neutral \\
\hline Neutral & 3 & $2.51-3.50$ & $2.51-3.50$ & \multirow{2}{*}{ Positive } \\
\hline Agree & 4 & $3.51-4.50$ & $3.51-5.50$ & \\
Strongly Agree & 5 & $4.51-5.50$ & & \\
\hline
\end{tabular}

However, for testing hypothesis each of the hypotheses handled individually and discussions presented based on Pearson Chi-Square, Phi value and df, where Chi-Square was used to "make inferences about the frequencies that was found in the respondents. A 5\% level significance was used for this study because as Neuman $(2000 ; 98)$ points out "the scientific community has informally agreed to use $5 \%$ level of significance as a standard rule of thumb for most purposes" (as cited in Myeza, 2008).

1. $\mathrm{H}_{0}$ : The attitude of Parents towards inclusion of Sex Education in school curriculum is neutral.

Table 3: Chi-Square testing for measuring parents' attitude

\begin{tabular}{llllll}
\hline & Frequency & Percent & Chi-Square(a) & df & Sig. \\
\hline Negative & 30 & 25.0 & & & \\
Neutral & 32 & 26.7 & 12.200 & 2 & $.002^{* *}$ \\
Positive & 58 & 48.3 & & & \\
Total & 120 & 100.0 & & Sources: Field Survey
\end{tabular}

Form the above table it was found that about half of parents(48.3\%)showed positive attitude towards inclusion of sex education in school curriculum, while $25 \%$ parents were not supportive and rests were in neutral position. However, the outcome for Chi-Square test found that $\chi^{2}=12.200$ at $\mathrm{df}=2$, wasvery statistically significant at .05 level, which means that there had differences between the attitude of parents towards inclusion 
of sex education in school curriculum. Therefore, thenull hypothesis was not accepted, so that it could be inferred that parents'attitude toward inclusion of Sex Education in school curriculum is not neutral.

2. $\mathrm{H}_{0}$ : There has no weighty difference in attitudeof rural and urban parents towards inclusion of Sex Education.

Table 4: Chi-Square testing for measuring influence of parents' residence

\begin{tabular}{|c|c|c|c|c|c|c|c|}
\hline & \multicolumn{2}{|c|}{ Parents residence } & \multirow[b]{2}{*}{ Total } & \multirow[b]{2}{*}{$\begin{array}{l}\text { Pearson } \\
\text { Chi-Square }\end{array}$} & \multirow[b]{2}{*}{ Phi } & \multirow[b]{2}{*}{$\mathrm{df}$} & \multirow[b]{2}{*}{$\begin{array}{l}\text { Sig. } \\
\text { (2-sided) }\end{array}$} \\
\hline & $\begin{array}{l}\text { Dhaka } \\
\text { (As Urban) }\end{array}$ & $\begin{array}{l}\text { Rajbari } \\
\text { (As Rural) }\end{array}$ & & & & & \\
\hline \multirow[t]{2}{*}{ Negative } & 10 & 20 & 30 & & & & \\
\hline & $8.3 \%$ & $16.7 \%$ & $25.0 \%$ & & & & \\
\hline \multirow{2}{*}{ Neutral } & 10 & & & & & & \\
\hline & $8.3 \%$ & $18.3 \%$ & $26.7 \%$ & 16178 & 367 & 2 & $000 * * *$ \\
\hline \multirow[t]{2}{*}{ Positive } & 40 & 18 & 58 & & & & \\
\hline & $33.3 \%$ & $15.0 \%$ & $48.3 \%$ & & & & \\
\hline \multirow[t]{2}{*}{ Total } & 60 & 60 & 120 & & & & \\
\hline & $50.0 \%$ & $50.0 \%$ & $100.0 \%$ & & & & \\
\hline
\end{tabular}

The overhead tableshowedthat urban parents' were more supportive than the rural parents in inclusion of sex education. The percentages were $33.3 \%$ and $15 \%$ respectively. However, the outcome of the analysis found $\chi^{2}=16.178$ at $\mathrm{df}=2$ and $\mathrm{p}<.001$, which wasremarkably statistically significant.Hence, the hypothesis was not accepted. Accordingly, it could be said that the residence of parents' remarkably influence their attitude in incorporating sex education in school curriculum of Bangladesh.

3. $\mathrm{H}_{0}$ : There is no significant difference between parents' attitude regarding inclusion of Sex Education irrespective of sexual orientation, religious belief, occupation, and level of education.

\section{i. Attitude vs. Parents Sexual Orientation}

Table 5: Chi-Square testing for measuring influence of parents' sexual orientation

\begin{tabular}{|c|c|c|c|c|c|c|c|}
\hline & \multicolumn{2}{|c|}{ Parents sexual orientation } & \multirow[b]{2}{*}{ Total } & \multirow{2}{*}{ Pearson Chi-Square } & \multirow{2}{*}{ Phi } & \multirow{2}{*}{$\mathrm{df}$} & \multirow{2}{*}{$\begin{array}{l}\text { Sig. } \\
\text { (2-sided) }\end{array}$} \\
\hline & Male & Female & & & & & \\
\hline Negative & $\begin{array}{l}18 \\
15.0 \%\end{array}$ & $\begin{array}{l}12 \\
10.0 \%\end{array}$ & $\begin{array}{l}30 \\
25.0 \%\end{array}$ & & & & \\
\hline Neutral & 14 & 18 & 32 & & & & \\
\hline Positive & $\begin{array}{l}11.7 \% \\
28\end{array}$ & $\begin{array}{l}15.0 \% \\
30 \\
25.0 \%\end{array}$ & $\begin{array}{l}26.7 \% \\
58\end{array}$ & 1.769 & .121 & 2 & .413 \\
\hline Total & $\begin{array}{l}60 \\
50.0 \%\end{array}$ & $\begin{array}{l}60 \\
50.0 \%\end{array}$ & $\begin{array}{l}120 \\
100.0 \%\end{array}$ & & & & \\
\hline
\end{tabular}

From the above table outcome showed that $\chi^{2}=1.769$ at $\mathrm{df}=2$ wasstatisticallynot significant at .05 level of significance. Therefore,the hypothesis wasupheld. Thus, it could be concluded that there was no difference between parents' attitude regarding inclusion of sex education irrespective of their sexual orientation.

\section{ii. Attitude vs. Religious Belief}

Table 6: Chi-Square testing for measuring influence of parents' religious belief

\begin{tabular}{|c|c|c|c|c|c|c|c|c|c|}
\hline & \multicolumn{4}{|c|}{ Parents religion } & \multirow[b]{2}{*}{ Total } & \multirow{2}{*}{$\begin{array}{l}\text { Pearson } \\
\text { Square }\end{array}$} & \multirow{2}{*}{${ }^{\text {Chi- }}$ Phi } & \multirow{2}{*}{ df } & \multirow{2}{*}{$\begin{array}{l}\text { Sig. } \\
\text { (2-sided) }\end{array}$} \\
\hline & Muslim & Buddhist & Hindu & Christian & & & & & \\
\hline \multirow[t]{2}{*}{ Negative } & 26 & 2 & 2 & 0 & 30 & \multirow{8}{*}{8.534} & \multirow{8}{*}{.267} & \multirow{8}{*}{6} & \multirow{8}{*}{.202} \\
\hline & $21.7 \%$ & $1.7 \%$ & $1.7 \%$ & $.0 \%$ & $25.0 \%$ & & & & \\
\hline \multirow[t]{2}{*}{ Neutral } & 26 & 4 & 2 & 0 & 32 & & & & \\
\hline & $21.7 \%$ & $3.3 \%$ & $1.7 \%$ & $.0 \%$ & $26.7 \%$ & & & & \\
\hline \multirow[t]{2}{*}{ Positive } & 40 & 4 & 12 & 2 & 58 & & & & \\
\hline & $33.3 \%$ & $3.3 \%$ & $10.0 \%$ & $1.7 \%$ & $48.3 \%$ & & & & \\
\hline \multirow[t]{2}{*}{ Total } & 92 & 10 & 16 & 2 & 120 & & & & \\
\hline & $76.7 \%$ & $8.3 \%$ & $13.3 \%$ & $1.7 \%$ & $100.0 \%$ & & & & \\
\hline
\end{tabular}

Note. $\mathrm{p}>5 \%$ level of significance

Sources: Field Survey 
The result presented in overhead table that $\chi^{2}=8.534$ at $\mathrm{df}=6$ was not statistically significant at .05 level of significance.Therefore, the hypothesis wasaccepted; hence it could be settled that in terms of parents' religious belief their attitude towards inclusion of sex education found no differences.

\section{iii. Attitude vs. Parents Occupation}

Table 7: Chi-Square testing for measuring influence of parents' occupation

\begin{tabular}{|c|c|c|c|c|c|c|c|c|c|c|c|}
\hline & \multicolumn{6}{|c|}{ Parents occupation } & \multirow[b]{2}{*}{ Total } & \multirow[b]{2}{*}{$\begin{array}{l}\text { Pearson } \\
\text { Chi-Square }\end{array}$} & \multirow[b]{2}{*}{ Phi } & \multirow[b]{2}{*}{ df } & \multirow[b]{2}{*}{$\begin{array}{l}\text { Sig. } \\
\text { (2-sided) }\end{array}$} \\
\hline & Business & Housewife & Teacher & $\begin{array}{l}\text { Service } \\
\text { holder }\end{array}$ & $\begin{array}{l}\text { Social } \\
\text { worker }\end{array}$ & $\begin{array}{l}\text { Day } \\
\text { labor }\end{array}$ & & & & & \\
\hline \multirow[t]{2}{*}{ Negative } & 8 & 6 & 0 & 8 & 2 & 6 & 30 & \multirow{8}{*}{40.988} & \multirow{8}{*}{.584} & \multirow{8}{*}{10} & \multirow{8}{*}{$.000 * * *$} \\
\hline & $6.7 \%$ & $5.0 \%$ & $.0 \%$ & $6.7 \%$ & $1.7 \%$ & $5.0 \%$ & $25.0 \%$ & & & & \\
\hline \multirow[t]{2}{*}{ Neutral } & 8 & 14 & 4 & 2 & 2 & 2 & 32 & & & & \\
\hline & $6.7 \%$ & $11.7 \%$ & $33 \%$ & $1.7 \%$ & $1.7 \%$ & $1.7 \%$ & $26.7 \%$ & & & & \\
\hline \multirow[t]{2}{*}{ Positive } & 6 & 8 & 10 & 26 & 8 & 0 & 58 & & & & \\
\hline & $5.0 \%$ & $6.7 \%$ & $83 \%$ & $21.7 \%$ & $6.7 \%$ & $.0 \%$ & $483 \%$ & & & & \\
\hline \multirow[t]{2}{*}{ Total } & 22 & 28 & 14 & 36 & 12 & 8 & 120 & & & & \\
\hline & $183 \%$ & $233 \%$ & $11.7 \%$ & $30.0 \%$ & $10.0 \%$ & $6.7 \%$ & $100.0 \%$ & & & & \\
\hline
\end{tabular}

From the above table, the result of the analysis found that $\chi^{2}=40.988$ at $\mathrm{df}=10$, where $\mathrm{p}<.001$, whichwas considered to be extremely statistically remarkable significant. Therefore, the hypothesiswas not upheld. For instance, it could be inferred that there was weighty difference in between parents' attitude towards inclusion of sex education in school curriculum and their occupation.

\section{iv. Attitude vs. Parents Level Of Education}

Table 8: Chi-Square testing for measuring influence of parents' educational background

\begin{tabular}{|c|c|c|c|c|c|c|c|c|c|c|}
\hline & \multicolumn{5}{|c|}{ Parents level of education } & & \multirow[b]{2}{*}{$\begin{array}{l}\text { Pearson } \\
\text { Chi-Square }\end{array}$} & \multirow[b]{2}{*}{ Phi } & \multirow[b]{2}{*}{$\mathrm{df}$} & \multirow[b]{2}{*}{$\begin{array}{l}\text { Sig. } \\
\text { (2-sided) }\end{array}$} \\
\hline & $\begin{array}{l}\text { Primary } \\
\text { graduate }\end{array}$ & $\begin{array}{l}\text { Secondary } \\
\text { school } \\
\text { certificate }\end{array}$ & $\begin{array}{l}\text { Higher } \\
\text { secondary } \\
\text { certificate }\end{array}$ & Graduate & $\begin{array}{l}\text { Post } \\
\text { graduate }\end{array}$ & Total & & & & \\
\hline$\overline{\text { Negative }}$ & $\begin{array}{l}12 \\
10.0 \%\end{array}$ & $\begin{array}{l}4 \\
3.3 \%\end{array}$ & $\begin{array}{l}12 \\
10.0 \%\end{array}$ & $\begin{array}{l}2 \\
1.7 \%\end{array}$ & $\begin{array}{l}0 \\
.0 \%\end{array}$ & $\begin{array}{l}30 \\
25.0 \%\end{array}$ & & & & \\
\hline Neutral & 6 & 8 & 14 & 4 & 0 & 32 & & & & \\
\hline Positive & $\begin{array}{l}5.0 \% \\
0 \\
.0 \%\end{array}$ & $\begin{array}{l}6.7 \% \\
2 \\
1.7 \%\end{array}$ & $\begin{array}{l}11.7 \% \\
4 \\
3.3 \%\end{array}$ & $\begin{array}{l}3.3 \% \\
42 \\
35.0 \%\end{array}$ & $\begin{array}{l}.0 \% \\
10 \\
8.3 \%\end{array}$ & $\begin{array}{l}26.7 \% \\
58 \\
48.3 \%\end{array}$ & 84.916 & .841 & 8 & $.000^{* * *}$ \\
\hline Total & $\begin{array}{l}18 \\
15.0 \%\end{array}$ & $\begin{array}{l}14 \\
11.7 \%\end{array}$ & $\begin{array}{l}30 \\
25.0 \%\end{array}$ & $\begin{array}{l}48 \\
40.0 \%\end{array}$ & $\begin{array}{l}10 \\
8.3 \%\end{array}$ & $\begin{array}{l}120 \\
100.0 \%\end{array}$ & & & & \\
\hline
\end{tabular}

The result of the analysis was $\chi^{2}=84.916$ at $\mathrm{df}=8$ and $\mathrm{p}<.001$, which was remarkably statistically significant. The study found parents who were graduate or post-graduate their attitude towards inclusion of sex education were very much positive than the any other groups. Therefore, the null hypothesis was statistically not accepted, accordingly it was cleared that in terms of parents' level of education their attitude towards inclusion sex education found significantly changed.

\section{Discussion}

The majority of the parents in this study were found supportive on educating sex education. About $48.3 \%$ parents showed positive attitude, whereas $25 \%$ parents stated negativeattitude towards inclusion of sex education in school curriculum and rests couldn't ensure their side on whether positive or negative so that they revealed in neutral position. Inthe context of Bangladesh it may be, parents were motivated by the existing social values and religious norms. Therefore, this reason many of the parents do not know what should be their answer. Form the Chi-square testofthe first hypothesis, the study also found that parents'attitude regarding sex education was not neutral. Though, parents' ratedsome topics to include in sex education curriculum for school going children, but most of the topics parents agreed to include in thecurriculum were value oriented and on prior knowledge of sex and sexuality instead of introducing with safer sexual relation. They approved family information and family values, tolerance and respect towards the opposite sex eliminating gender based violence, positive contact with family members about sexuality in adolescent period, and knowledge about adolescents' physical and mental change along with knowledge on sexually transmitted infections (STIs) including HIV/AIDS, and sexual abuse and harassment topics to include in curriculum. Majority of the parents refused to include the topics those were highly essential to be equipped to protect unsafe and risky sexual 
behavior. The topics most of the parents refused to incorporate in school curriculum were practicability of knowledge to establish a sexual relationship of ante-nuptials, healthy and safe physical sexual relation, decision about sexual relation, contraception and natural way of sexual planning, reproduction and pregnancy, teenage parenthood and its risk, and reproductive organs and their functions of male and female. These findings supported previous study conducted in Malaysia (Makol-Abdul, Nurullah, Imam, \& Rahman, 2009). It seemed that parents were more conscious about abstinence than protection and safer sexual relation. Moreover, form the study it could be observedthat parentssupported on that topics sex education what was their own culture sensitive, which might be designated according to their social and religious norms and values. Some of the previous studies found similar reflection (Kabir, Karim, \& Akhter, 2005; Sanjakdar, 2004; Bennett, 2007). Likewise, the study found that parents' did not support to include the topics like abortion, sex work, prostitution, and knowledge about performing sexual intercourse, premarital sex and sexual decision making should not be included as sex education topic, which corroborated withone of the previous study for Malaysian samples (Makol-Abdul, Nurullah, Imam, \& Rahman, 2009).In contrast, this finding did not corroborate with Canadian samples where parents suggested a complete sex education program that includes a wide range of issues those go beyond biology including sexual decision making, sexual pleasure and enjoyment (Weaver, Byers, Sears, Cohen, \& Randall, 2002).

However,one of the major purposes of this study was to find out the difference between rural and urban parents attitude. The findings illustrated that about $30 \%$ of rural parents were positive towards sex education whereas it was $66.6 \%$ among the urban parents. In contrast, $33.4 \%$ of rural parents possessed negative attitude towards the education when it was $16.6 \%$ among urban parents. From Chi-Square test the study also found that there was remarkablysignificant difference between the attitude of rural parents and urban parents.

The third purpose of the study was to find out the relation between parents' attitude and their demographic characteristics. The demographic characteristics covered four important variable, these weresexual orientation, religious belief, occupation and educational background of the parents. The study found that there wasno significance difference between parental sexual orientation and their attitude, so that it could be concluded that the attitudes of male and female respondents were indifference regarding inclusion of sex education in school curriculum. The same result found in terms of parental religious belief, but it should be needed to quote that parents from others religion except Islam were very little in the sample size. The result for parental sexual orientation with their attitude did not agree with the previous study conducted with Malaysian samples (Makol-Abdul, Nurullah, Imam, \& Rahman, 2009). However, the most interesting things was that when it came to parent occupation and educational background, their attitude towards incorporating sex education in school curriculum found noteworthy difference. From Chi-square test the hypotheses were rejected undoubtedly regarding parents' attitude towards inclusion of sex education and their occupation and educational background. In this study parents' found in six occupations, where teaching profession and service holders group of parents showed positive attitude most. In contrast, parents who were day labor they didnot support to include sex education in school curriculum. Likewise, lower literacy rate also one of the main reasons for possessing such types of attitude towards sex education. These findings agreed with the study conducted in Malaysia (MakolAbdul, Nurullah, Imam, \& Rahman, 2009). Therefore, from the study it could be illustrated that parents'attitude towards sexuality education are correlated with their level of education and their occupations.

\section{Limitation and Further Study Suggestions}

The findings of the study must be precise in light of its limitation. First, the respondents were chosen from only two areas with small size of sampling so that the findings would not be generalized to all Bangladeshi parents'. The respondents covering more areas with a large size of sampling could be considered and it might explore difference findings. Second, most of the people in Bangladesh consider sex as a malicious word and a significant part of parents were unwilling to discuss or provide information on this issue. Third, in the context of Bangladesh there were few works found on this issue. More importantly, exploring parents' attitude on this issue was very new in the context of Bangladesh. Therefore, the findings of this study could not be verified with other works. Finally, a representative sample was not feasible due to resources and time limitations. It is generally accepted that every researcher is dogged by money, manpower and time (Blalock, 1987). However, further research works should use heterogeneous larger representative samples of rural and urban parents and use multiple sources of data collection.

\section{Conclusion}

Previous research showed that sex education is a neglected term in Bangladesh and there has no integrated plan to provide sex educationforschool going children. As most of the parents have lack of proper knowledge regarding sex education therefore they are not comfortable to discuss the issue with their children. Hence, the children are being misguided along with creating various social and health risks. In this context there is an argument going on from the civil society for inclusion of sex education in formal education for a very long 
time. However, due to lack of study on this issue in national context the argument remain weightless and this study will surely add a growing body of literature documenting Bangladeshi parents' attitude and support for the inclusion of sex education in school curriculum. Therefore, the studyalong with previous study in this field is the beginning of a platform for discussion among the citizen including the stakeholders of education in the country. Hope the study findings will help to the concerned authority to take some vital actions for inclusion of sex education in school curriculum to protect future parents from different sort of sexual diseases, HIV/AIDS, unwanted pregnancy, premature death and so on.

\section{References}

[1]. Government of the People's Republic of Bangladesh. (2004). Bangladesh Population Policy. Dhaka: Ministry of Health and Family Welfare, Government of the People's Republic of Bangladesh.

[2]. Teen Pregnancy Rates Go Back Up. (2009, 26 February). Retrieved November 27, 2011, from BBC News: http://news.bbc.co.uk/2/hi/uk_news/7911684.stm

[3]. Comprehensive Sexuality Education. (2011, June). Retrieved December 3, 2011, from SIECUS: http://www.siecus.org/index.cfm?fuseaction=page.viewPage\&pageId=514\&parentID=477

[4]. Sexually Transmitted Diseases and STD Symptoms. (2011). Retrieved November 13, 2011, from http://www.avert.org/stds.htm

[5]. The Reproductive Rights of Adolescents: A Tool for Health and Empowerment. (2011, December 4). Retrieved from Center for Reproductive Rights: http://reproductiverights.org/sites/crr.civicactions.net/files/documents/adolescents\%20bp_FINAL.pdf

[6]. Adler, M. (1993). Parental Choice and the Enhancement of Children's Interests. In P. Munn (Ed.), Parents and Schools: Customers, Managers or Partners. London: Routledger.

[7]. Athar, S. (1995). Sex Education: An Islamic Perspective. Chicago: Kazi Publications Inc.

[8]. Barkat, A., \& Majid, M. (2003). Adolescent Reproductive Health in Bangladesh. Dhaka, Bangladesh: POLICY Project.

[9]. Bennett, L. P. (2007). Zina and enigma of sex education for Indonesian Muslims youth. Sex Education, 371-386.

[10]. Blalock, H. M. (1987). Social Statistics. Singapore: McGraw-Hill.

[11]. CEDAW. (1990). CEDAW General Recommendation No. 15: Avoidance of Discrimination against Women in National Strategies for the Prevention and Control of Acquired Immunodeficiency Syndrome (AIDS). UN Committee on the Elimination of Discrimination against Women (CEDAW). Retrieved December 5, 2011, from http://www.unher.org/refworld/docid/453882a311.html

[12]. Creswell, J. W. (2003). Research Design: Qualitative, quantitative, and mixed methods approaches. Thousand Oaks, CA: Sage Publication.

[13]. Eggleston, E., Jackson, J., Rountree, W., \& Pan, Z. (2000, June). Evaluation of Sexuality Education Programme for Young Adolescents in Jamaica. RevistaPanamericana de SaludPublica/Pan American Journal of Public Health (RPSP/PAJPH), 102-112.

[14]. Erulkar, A. S., Ettyang, L. I., Onoka, C., Nyagah, F. K., \&Muyonga, A. (2004). Behavior Change Evaluation of a Culturally Consistent Reproductive Health Program for Young Kenyans. International Family Planning Perspective, 30(2), 58-67.

[15]. Fawole, I. O., Asuzu, M. C., Oduntan, S. O., \&Brieger, W. R. (1999). A School-based AIDS Education Programme for Secondary School Students in Nigeria: A Review of Effectiveness. Health Education Research, 14(5), 675-683. Retrieved December 14, 2011, from http://her.oxfordjournals.org/content/14/5/675.full.pdf

[16]. Frappier, J. Y., Kaufman, M., Baltzer, F., Elliott, A., Lane, M., Pinzon, j., \&McDuff, P. (2008, January). Sex and Sexual Health: A Survey of Canadian Youth and Mothers. (U. o. Montreal, Ed.) Paediatr Child Health, 13(1), 25-30.

[17]. Fulton, E. L., Kamal, N., Ahmed, S. M., \& Khan, M. I. (1997). Determinants of AIDS Awareness and Knowledge among Rural Men and Women in Bangladesh. Dhaka, Bangladesh: ICCDR,B.

[18]. Gay, L. R. (1996). Educational Research: Competencies for Analysis and Applications. NJ: Prentice-Hall Inc.

[19]. Government of the People's Republic of Bangladesh. (n.d.). National Strategic Plan for HIV/AIDS 2004-2010. Bangladesh: National AIDS/STD Programme (NASP), Directorate General of Health Services, Ministry of Health \& Family Welfare.

[20]. Haseen, F., Larson, C. P., Nahar, Q., Huq, N. L., Quaiyum, M. A., Reza, M., \&Aboud, F. (2004). Evaluation of a School-based Sexual and Reproductive Health Education Intervention among Adolescents in Rural Bangladesh. Dhaka, Bangladesh: ICDDR,B: Centre for Health and Population Research.

[21]. Holmes, K. K., Sparling, P. F., Stamm, W. E., Pito, P., Wasserheit, J. N., Corey, L., Watts, D. H. (2007). Sexually Transmitted Diseases (4th ed.). New York, USA: The McGraw-Hill Companies, Inc.

[22]. Kabir, E., Karim, R., \& Akhter, F. (2005). The Need for Sexuality Education in Bangladesh. Dhaka, Bangladesh: Newsnetwork.

[23]. Kirby, D., \&Laris, B. A. (2009). Effective Curriculum-Based Sex and STD/HIV Education Programs for Adolescents. Child Development Perspectives. Retrieved from http://www.moappp.org/Documents/events/2009/KirbyLarisArticle.pdf

[24]. Kirby, D., Laris, B. A., \&Rolleri, L. (2006). Sex and HIV Education Programs for Youth: Their Impact and Important Characteristics. Scotts Valley, U.S.S.: Family Health International (YFI).

[25]. Landry, D. J., Singh, S., \&Darroch, J. E. (2000, September/October). Sexuality Education in Fifth and Sixth Grades in U.S. Public Schools. Guttmacher Institute, 32(5). Retrieved November 19, 2011, from http://www.guttmacher.org/pubs/journals/3221200.html Makol-Abdul, P. R., Nurullah, A. S., Imam, S. S., \& Rahman, S. A. (2009). Parents' Attitude towards Inclusion of Sexuality Education in Malaysian Schools. International Journal about Parents in Education, 3(1), 42-56.

[26]. McMillan, J. H., \& Schumacher, S. (1993). Research in education: A conceptual introduction. New York, NY: HarperCollins College Publishers.

[27]. Myeza, N. P. (2008). Attitude of High School Learners towards Sexuality Education in Zululand. University of Zululand, Department of Psychology, Zululand, South Africa

[28]. Nahar, Q., Amin, S., Sultan, R., Nazrul, H., Islam, M., Kane, T. T., Tunon, C. (1999). Strategies to Meet the Healtha Needs of Adolescents: A Review. (M. S. Khan, Ed.) (Special Publication no. 91).

[29]. National AIDS Committee. (1996). National Policy on HIV/AIDS and STD Related Issues. Bangladesh: Directorate General of Health Services, Ministry of Health and Family Welfare, Government of the People's Republic of Bangladesh.

[30]. PLAN. (2010). Sexuality Education in Asia: Are We Delivering? UK: PLAN International.

[31]. Sanjakdar, F. (2004). Developing appropriate sexual health education curriculum framework for Muslim students. In B. v. Driel (Ed.), Confronting Islamaphobia in educational practice (pp. 143-162). Sterling, Staffordshire: Trentham Books.

[32]. Sex Education in Asia. (n.d.). Retrieved November 13, 2011, from CheekeeWidit: http://www.cheekee-widit.com/sex-education-inasia.html 
[33]. Sex Information and Education Council of Canada (SIECCAN). (2009). Sexual Health Education in the Schools: Questions \& Answers. Toronto, Ontario, Canada: Sex Information and Education Council of Canada (SIECCAN). Retrieved December 12, 2011, from http://www.sieccan.org/pdf/she_q\%26a_3rd.pdf

[34]. Shafiq, M. S. (2011). Behavioural Change of Adolescents through Peer Education Program. Unpublished Dissertation, Institute of Education and Research, University of Dhaka, Nonformal and Continuing Education.

[35]. Slater, J. (2000). Britain: Sex Education under Fire. (J. Burnet, Ed.) The Courier, 53(7), 17-18. Retrieved from http://www.unesco.org/courier

[36]. UNAIDS. (2008). The Global AIDS Epidemic. Geneva, Switzerland: UNAIDS.

[37]. UNAIDS. (2009). AIDS Epidemic Update. Geneva, Switzerland: UNAIDS.

[38]. UNAIDS. (2010). The Global AIDS Epidemic. Geneva, Switzerland: UNAIDS.org.

[39]. UNESCO. (2009). International Guidelines on Sexuality Education: An Evidence Informed Approach to Effective Sex, Relationships and HIV/STI Education. France: UNESCO.

[40]. UNFPA; State of World Population. (2003). Investing the Adolescents' Health and Rights. New York, U.S.A.: UNFPA.

[41]. UNICEF. (2010, January 20). Millennium Development Goals. Retrieved November 27, 2011, from UNICEF (United Nations International Children's Emergency Fund): http://www.unicef.org/statistics/index 24304.html

[42]. UNICEF. (2011). Opportunity in Crisis: Preventing HIV from early adolescence to young adulthood. New York: United Nations Children's Fund (UNICEF).

[43]. United Nations. (1948). The Universal Declaration of Human Rights. United Nations (UN). Retrieved November 29, 2011, from http://www.un.org/en/documents/udhr/index.shtml

[44]. Weaver, A. D., Byers, E. S., Sears, H. A., Cohen, J. N., \& Randall, H. E. (2002). Sexual Health Education at School and at Home: Attitude and Experiences of New Brunswick Parents. The Canadian Journal of Human Sexuality.

[45]. WHO, UNAIDS, UNICEF. (2011). Global HIV/AIDS Response. Geneva, Switzerland: World Health Organization, Department of HIV/AIDS.

[46]. Wilson, K., \&Keelan, J. (2008). Learning from Listeria: theautonomy of the Public Health Agency of Canada. www.cmaj.ca. doi:10.1503/cmaj.081441 